\title{
Perbandingan Efektifitas Klinis antara Kloramfenikol dan Tiamfenikol dalam Pengobatan Demam Tifoid padaAnak
}

\author{
Rismarini, Zarkasih Anwar, Abbas Merdjani
}

\begin{abstract}
Demam tifoid masih merupakan masalah kesehatan di Indonesia dan kloramfenikol masih merupakan pilihan utama untuk pengobatan demam tifoid. Dari beberapa penelitian di temukan 3-8\% kuman Salmonella telah resisten terhadap kloramfenikol, 2-4\% mengalami kekambuhan dan menjadi pengidap kuman, disamping adanya efek samping penekanan sumsum tulang dan anemia aplastik. Seftriakson dan siprofloksasin dapat memberikan hasil yang lebih baik tetapi belum dapat dipakai secara luas karena harganya mahal. Penelitian ini bertujuan untuk menguji perbandingan efektifitas klinis kloramfenikol dan tiamfenikol dalam pengobatan demam tifoid pada anak.

Penelitian uji acak tersamar ganda dilakukan pada anak dengan demam tifoid yang dirawat dibagian IKA FK UNSRI / RS Moh Husein (RSMH) Palembang antara Maret Nopember 1999. Lima puluh orang anak memenuhi kriteria penelitian, terdiri dari 27 anak laki-laki dan 23 anak perempuan, $41(82 \%)$ anak usia 5 tahun atau lebih, hanya 9 (18\%) usia di bawah 5 tahun. Dua puluh lima anak mendapat kloramfenikol, yang lain mendapat tiamfenikol. Pada kelompok kloramfenikol demam kembali normal dalam waktu 3,04 $\pm 2,11$ hari sedangkan dengan tiamfenikol dalam waktu 2,68 \pm 1,57 hari. Secara statistik tidak ditemukan perbedaan bermakna dalam hal lamanya turun demam, membaiknya nafsu makan, hilangnya nyeri perut serta pulihnya kesadaran antara kelompok kloramfenikol dengan kelompok tiamfenikol. Terdapat 1 penderita yang tidak sembuh dengan kloramfenikol sehingga diganti dengan seftriakson, sementara dari kelompok tiamfenikol semuanya sembuh. Tidak ditemukan pasien yang kambuh dan pengidap kuman setelah pengobatan. Kejadian anemia selama pengobatan sama pada kedua kelompok. Walaupun tidak berbeda secara bermakna, kelompok tiamfenikol dapat keluar rumah sakit 1 hari lebih cepat sedangkan harga obat hanya sedikit lebih mahal dari kloramfenikol.
\end{abstract}

Kata kunci: kloramfenikol, tiamfenikol, resistensi.

D emam tifoid masih merupakan masalah kesehatan di negara berkembang. Di Indonesia insidens masih sangat tinggi, diperkirakan ada sekitar 350-810 kasus per 100.000 populasi per tahun, atau sekitar $600.000-1,5$ juta pasien per tahun dengan angka kematian 1,5-3,4\%. ${ }^{1,2}$ Di

Alamat korespondensi:

Dr. Rismarini, Sp.A.

Bagian IKA FK-UNSRI/RS Moh Husein Palembang. Jl. Jendral Sudirman km 3,5 Palembang

Telepon: 0711-354088 ext. 364/226. Fax: 0711-372832 / 54087. bagian IKA FK UNSRI / RSUMH Palembang pada tahun 1998 dirawat 169 (6\%) kasus demam tifoid dari 2.828 pasien rawat inap. ${ }^{3}$

Kloramfenikol masih merupakan pilihan utama untuk pengobatan demam tifoid karena efektif, murah, mudah didapat dan dapat diberikan secara oral. Umumnya perbaikan klinis sudah tampak dalam waktu 72 jam dan suhu akan kembali normal dalam waktu 3-6 hari, dengan lama pengobatan antara 10-14 hari. ${ }^{4,5}$ Dari beberapa penelitian didapatkan sekitar 3-8\% galur Salmonella setelah resisten terhadap kloramfenikol., ${ }^{2,7}$ Angka kekambuhan dan pengidap kuman setelah 
pengobatan terjadi pada sekitar 2-4\% kasus. ${ }^{5}$ Disamping itu pemakaian kloramfenikol dapat menimbulkan efek samping berupa penekanan sumsum tulang dan yang paling ditakuti terjadinya anemia aplastik. ${ }^{2,5}$ Di bagian IKA FK UNSRI / RSUMH Palembang belum didapatkan gambaran resistensi ini karena belum pernah dilakukan penelitian, tetapi secara klinis ditemukan beberapa kasus yang dicurigai resisten terhadap kloramfenikol.

Telah banyak penelitian mencari obat alternatif dalam pengobatan demam tifoid diantaranya seftriakson dan siprofloksasin adalah yang paling banyak diuji coba. ${ }^{2,4,8-13}$ Dengan obat tersebut demam turun lebih cepat, lama pengobatan lebih pendek, angka kesembuhan tinggi dan efek samping minimal. 9,10,11 Tetapi obat-obat tersebut belum dapat digunakan secara luas karena harganya yang mahal, disamping pemberian seftriakson secara injeksi yang tidak disukai anak serta sifat toksik siprofloksasin terhadap tulang mengganggu pertumbuhan tulang rawan. ${ }^{9,11}$ Kedua golongan obat tersebut di atas terutama ditujukan untuk galur Salmonella yang telah resisten terhadap obat standar. ${ }^{11,13,14}$

Tiamfenikol adalah turunan kloramfenikol yang juga aktif terhadap spesies Salmonella dan dapat diberikan secara oral. Obat dapat diberikan dengan dosis lebih kecil, interval lebih lama, dengan angka kekambuhan dan pengidap kuman lebih kecil Walaupun dapat menyebabkan depresi sumsum tulang tetapi hampir tidak pernah terjadi anemia aplastik. ${ }^{15-16}$ Dari penelitian pada pasien demam tifoid usia remaja dan dewasa didapatkan suhu kembali normal dalam waktu 3-5 hari dan lama pengobatan sekitar 10 hari. ${ }^{15-18}$ Penelitian ini bertujuan untuk menilai perbandingan efektifitas kloramfenikol dan tiamfenikol dalam pengobatan demam tifoid pada anak.

\section{Metodologi}

Penelitian ini suatu uji klinik acak tersamar ganda yang menguji efektifitas kloramfenikol dan tiamfenikol untuk pengobatan demam tifoid pada anak. Subjek penelitian adalah semua pasien demam tifoid anak yang dirawat di bangsal Infeksi bagian IKA FK UNSRI / RSUMH Palembang selama bulan Maret sampai dengan Nopember 1999. Sebagai kriteria inklusi adalah semua pasien yang dirawat tanpa kontraindikasi untuk pemberian kloramfenikol dan tiamfenikol, yaitu $\mathrm{Hb}$
$>8$ g\% dan leukosit $>2.000 /$ ul. Pasien dengan komplikasi dan pasien kambuhan tidak diikutkan dalam penelitian; sedangkan pasien dengan efek samping obat yang berat, tidak dapat di follow up sampai 3 hari bebas demam atau terbukti menderita penyakit lain dikeluarkan dari penelitian.

Besar sampel dihitung berdasarkan rumus :

$$
\mathrm{n}=\frac{(\mathrm{u}+\mathrm{v})^{2}\left(\mathrm{~d}_{1}^{2}+\mathrm{d}_{2}^{2}\right)}{\left(\mathrm{u}_{1}-\mathrm{u}_{2}\right)}
$$

Dari rumus di atas diperoleh subyek 23 anak untuk masing masing kelompok.

Semua pasien dilakukan anamnesis, pemeriksaan fisik dan izin orang tua untuk ikut penelitian. Kemudian dengan cara acak pasien dibagi menjadi 2 kelompok. Kelompok pertama mendapat pengobatan dengan kloramfenikol dosis $100 \mathrm{mg} / \mathrm{kg} \mathrm{BB} / \mathrm{hari}$, maksimum 2 gram per hari sedangkan kelompok yang lain mendapat tiamfenikol $50 \mathrm{mg} / \mathrm{kg} \mathrm{BB} /$ hari. Obat dibuat dalam bentuk sirup $125 \mathrm{mg} / 5 \mathrm{ml}$ dan diberi botol yang sama, diberikan dalam 4 dosis per hari.

Pada hari pertama perawatan diperiksa hemoglobin, leukosit, hitung jenis, uji Widal, biakan darah dan aspirasi sumsum tulang. Setiap hari dinilai perbaikan klinis terutama kesadaran, suhu tubuh, nafsu makan, nyeri perut dan kemungkinan adanya efek samping pemakaian obat. Pengukuran suhu dilakukan 3 kali sehari yaitu pada jam 08.00,14.00 dan 20.00 atau sewaktu-waktu bila terjadi peningkatan suhu tubuh. Antipiretik tidak diberikan kecuali bila suhu $>39,5^{\circ} \mathrm{C}$ diberikan parasetamol $50 \mathrm{mg} / \mathrm{kgBB} /$ hari dibagi 3 dosis untuk mengontrol hiperpireksia. Setelah 7 hari pengobatan dilakukan pemeriksaan ulang hemoglobin, leukosit, hitung jenis dan uji Widal bila pada pemeriksaan pertama titernya $<1 / 160$. Selama perawatan pasien mendapatkan istirahat dan diet yang sama sesuai standar profesi bagian IKA.

\section{Hasil Penelitian dan Pembahasan}

Selama kurun waktu penelitian didapatkan 63 pasien klinis demam tifoid yang dirawat. Dari 63 pasien tersebut 8 orang tidak memenuhi kriteria penelitian yaitu 4 orang dengan ensefalopati, 4 orang dengan sepsis. Lima puluh lima pasien dimasukkan dalam 
penelitian, 28 mendapat kloramfenikol dan 27 mendapat tiamfenikol. Dari 55 subjek tersebut 5 orang dikeluarkan dari penelitian; 3 orang terbukti menderita penyakit lain, 1 orang timbul urtikaria dan 1 orang mengalami anemia selama pengobatan dengan $\mathrm{Hb}<$ $8 \mathrm{~g} \%$ sehingga obat terpaksa dihentikan dan diganti dengan obat lain.

Dari 50 subjek yang dapat dianalisis untuk masingmasing kelompok 25 orang, terdiri dari 27 anak lakilaki dan 23 perempuan. Umur pasien berkisar antara 2 tahun 7 bulan sampai 13 tahun, dengan rerata 8,01 $\pm 2,8$ tahun, $82 \%$ usia di atas 5 tahun atau lebih. Secara statistik tidak ada perbedaan yang bermakna antara kelompok kloramfenikol dan kelompok tiamfenikol dalam hal umur, jenis kelamin, status gizi, lama sakit di rumah dan riwayat pengobatan sebelumnya (Tabel $1)$.

Dari anamnesis dan pemeriksaan fisis tidak ditemukan perbedaan yang bermakna dari gejala klinis pasien saat masuk rumah sakit antara kelompok yang mendapat kloramfenikol dan kelompok tiamfenikol (Tabel 2).

Dari pengamatan selama dirawat di rumah sakit, tampak perbaikan klinis pada kelompok tiamfenikol lebih cepat dibandingkan dengan kloramfenikol walaupun secara satatistik tidak berbeda bermakna (Tabel 3).

Secara keseluruhan pada kelompok tiamfenikol

Tabel 1. Karakteristik umum subjek penelitian

\begin{tabular}{|c|c|c|c|}
\hline \multirow{3}{*}{ Variabel } & \multicolumn{3}{|c|}{ Kelompok Penelitian } \\
\hline & Kloramfenikol & Tiamfenikol & $\rho$ \\
\hline & $(\mathrm{n}=25)$ & $(\mathrm{n}=25)$ & \\
\hline \multicolumn{4}{|l|}{ Umur (tahun) } \\
\hline$<5$ & 4 & 5 & 0,99 \\
\hline$\geq 5$ & 21 & 20 & \\
\hline \multicolumn{4}{|l|}{ Kelamin } \\
\hline Laki-laki & 17 & 10 & 0,08 \\
\hline Perempuan & 8 & 15 & \\
\hline \multicolumn{4}{|l|}{ Gizi } \\
\hline Baik & 14 & 18 & 0,37 \\
\hline Kurang & 11 & 7 & \\
\hline $\begin{array}{l}\text { Rerata lama sakit } \\
\text { di rumah (hari) }\end{array}$ & $6,8 \pm 1,9$ & $6,6 \pm 2,3$ & 0,94 \\
\hline \multicolumn{4}{|c|}{ Riwayat pengobatan } \\
\hline $\mathrm{Ya}$ & 24 & 24 & 1,00 \\
\hline Tidak & 1 & 1 & \\
\hline
\end{tabular}

demam lebih cepat turun 0,91 hari, dan pada hari ketujuh semua pasien dari kelompok ini suhu sudah kembali normal, sedangkan dari kelompok kloramfenikol ada 1 pasien masih demam sampai hari kesepuluh sehingga obat diganti dengan seftriakson. Pada umumnya gejala saluran cerna seperti hilangnya nafsu makan dan nyeri perut sudah membaik dalam 3 hari pengobatan. Pada kelompok tiamfenikol membaiknya nafsu makan 0,54 hari lebih cepat, dan hilangnya nyeri perut 0,85 hari lebih cepat dibanding kelompok kloramfenikol. Gangguan kesadaran pada umumnya sudah pulih dalam waktu 3 hari, sedang pada kelompok tiamfenikol 0,34 hari lebih cepat dari pada kelompok kloramfenikol.

Dari penelitian ini terlihat bahwa efektifitas klinis kloramfenikol dan tiamfenikol dalam pengobatan

Tabel 2. Gambaran klinis penderita saat masuk rumah sakit

\begin{tabular}{|c|c|c|c|}
\hline \multirow{3}{*}{ Klinis } & \multicolumn{2}{|c|}{ Kelompok Penelitian } & \multirow{3}{*}{$\rho$} \\
\hline & Kloramfenikol & Tiamfenikol & \\
\hline & $(\mathrm{n}=25)$ & $(\mathrm{n}=25)$ & \\
\hline $\begin{array}{r}\text { Lama sakit } \\
\text { (hari) }\end{array}$ & $6,8 \pm 1,9$ & $6,8 \pm 2,3$ & 0,94 \\
\hline $\begin{array}{l}\text { Suhu tubuh } \\
\qquad\left({ }^{0} \mathrm{C}\right)\end{array}$ & $37,8 \pm 0,8$ & $38,1 \pm 0,8$ & 0,15 \\
\hline Muntah & 16 & 14 & 0,77 \\
\hline Nyeri perut & 17 & 17 & 1,00 \\
\hline Daire & 8 & 4 & 0,32 \\
\hline Obstipasi & 11 & 12 & 0,99 \\
\hline Anoreksia & 25 & 25 & 1,00 \\
\hline Rhagaden & 11 & 16 & 0,25 \\
\hline Lidah tifoid & 17 & 20 & 0,51 \\
\hline Hepatomegali & 14 & 16 & 0,77 \\
\hline Gangguan kesadaran & 5 & 5 & 1,00 \\
\hline
\end{tabular}

Tabel 3. Lama hari yang dibutuhkan untuk perbaikan klinis

\begin{tabular}{lccc}
\hline & \multicolumn{3}{c}{ Kelompok Penelitian } \\
\cline { 2 - 3 } Klinis & \multirow{2}{*}{\begin{tabular}{l} 
Kloramfenikol \\
\cline { 2 - 3 }
\end{tabular}} & Tiamfenikol \\
\cline { 2 - 3 } & $(\mathrm{n}=25)$ & $(\mathrm{n}=25)$ & \\
\hline Demam & $3,0 \pm 2,1$ & $2,7 \pm 1,6$ & 0,50 \\
Anoreksia & $2,5 \pm 1,3$ & $2,1 \pm 1,2$ & 0,25 \\
Nyeri perut & $2,1 \pm 1,6$ & $1,8 \pm 1,1$ & 0,55 \\
Gangguan kesadaran $1,6 \pm 1,1$ & $1,6 \pm 0,9$ & 0,99 \\
\hline
\end{tabular}


demam tifoid pada anak sangat baik. Walaupun tidak bermakna secara statistik, tetapi tiamfenikol menghasilkan perbaikan klinis yang lebih cepat dibandingkan dengan kloramfenikol. Secara anamnesis 48 anak sudah pernah mendapat pengobatan sebelumnya, tetapi tidak didapatkan data yang jelas mengenai obatobat yang pernah didapat. Kemungkinan ada pasien yang sudah mendapat kloramfenikol atau tiamfenikol ataupun obat-obat lain yang masih efektif untuk demam tifoid seperti ampisilin, amoksisilin atau kotrimoksazol yang kebetulan termasuk dalam kelompok tiamfenikol sehingga waktu masuk rumah sakit sudah dalam keadaan yang agak membaik, sedangkan dalam kelompok kloramfenikol lebih banyak pasien yang hanya mendapat terapi simtomatis seperti analgetik-antipiretika atau roboransia saja. Tetapi bila melihat gejala klinis kedua kelompok pada saat masuk rumah sakit (Tabel 2), pasien dari kelompok tiamfenikol lebih unggul dari pada kloramfenikol, walaupun perbedaannya tidak bermakna secara statistik.

Ditemukan 1 pasien dari kelompok kloramfenikol dengan demam sampai hari ke 10 pengobatan. Sebelum masuk rumah sakit pasien ini sudah mendapat pengobatan selama 4 hari, dengan jenis dan dosis yang tidak diketahui dengan pasti. Secara klinis pasien ini dianggap resisten terhadap kloramfenikol, kemudian obat diganti dengan seftriakson dan suhu kembali normal setelah 5 hari pengobatan.

Hasil biakan 50 spesimen darah didapatkan 5 (10\%) positif, sedangkan dari 32 aspirasi sumsum tulang didapatkan $21(65,6 \%)$ positif. Dua puluh enam isolat tersebut semuanya adalah $S$. typhi dan masih sensitif terhadap kloramfenikol dengan rerata zona hambat 28 $\mathrm{mm}$. Satu pasien yang secara klinis dianggap resisten terhadap kloramfenikol, sayangnya dari biakan darah tidak didapatkan pertumbuhan kuman sedangkan aspirasi sumsum tulang tidak dilakukan karena keluarga menolak sehingga sensitifitas invitro tidak dapat dievaluasi. Uji sensitifitas terhadap tiamfenikol tidak dapat dilakukan oleh karena National Commite for Clinical Laboratory Standard (NCCLS) hanya mengeluarkan cakram kloramfenikol, dan uji sensitifitas terhadap ampisilin dan kotrimoksaxol, ternyata semuanya masih sensitif terhadap kedua macam obat tersebut. Hasil uji sensitifitas ini sama dengan penelitian Soewandjoyo yang mendapatkan $100 \%$ isolat S. typhi masih sensitif terhadap kloramfenikol, ${ }^{12}$ sedangkan Nathin dan Soelistiowati mendapatkan 3,2-8\% isolat sudah resisten terhadap kloramfenikol. ${ }^{4,6}$

Selama kurun waktu penelitian tidak ditemukan kasus yang kambuh. Dari 50 subjek, hanya 27 pasien yang dapat dilakukan biakan feses dan urin 2 minggu setelah keluar dari rumah sakit, 15 dari kelompok kloramfenikol dan 12 dari kelompok tiamfenikol, hasilnya semua steril. Tidak ditemukan kasus kambuh atau pengidap kuman ini mungkin karena sedikitnya subjek yang diteliti. Azhali melaporkan angka kekambuhan dan pengidap kuman terjadinya pada 2 $-4 \%$ kasus. $^{5}$

Selama pemakaian obat, ditemukan 1 pasien yang timbul urtikaria pada pemakaian kloramfenikol, pasien ini dikeluarkan dari penelitian dan obat diganti dengan seftriakson. Ditemukan 5 pasien yang mengalami anemia selama pengobatan, 3 dari kelompok kloramfenikol dan 2 dari kelompok tiamfenikol $(p=0,67)$. Sebelum pengobatan, kadar hemoglobin pasien ini berkisar antara 9,5-11,4 g\%. Empat orang di antaranya dilakukan aspirasi sumsum tulang, 2 orang dengan gambaran sumsum tulang normal sedangkan pada 2 orang tampak hipoplasi ringan. Seminggu setelah pengobatan $\mathrm{Hb}$ pasien berkisar antara 8,4-9,5 g\% dengan retikulosit antara $0,4-1 \%$. Satu pasien yang dikeluarkan dari penelitian ini juga mengalami anemia selama pengobatan dengan tiamfenikol, dengan $\mathrm{Hb}<8 \mathrm{~g} \%$ dan retikulosit $0,2 \%$. Pada penelitian ini tidak dapat dipastikan apakah anemia terjadi karena pengaruh endotoksin dari S. typhi atau akibat pemakaian kloramfenikol dan tiamfenikol, oleh karena tidak dilakukan aspirasi sumsum tulang selama pemakaian obat. Dalam penelitiannya Nathin dan Soewandjoyo masing-masing mendapatkan 2 orang mengeluh gatal pada pemakaian kloramfenikol, sedangkan anemia yang ditemukan sebelum pengobatan kembali normal selama atau setelah pengobatan. Limson melaporkan 2 orang mengeluh muntah dan 1 orang menderita anemia selama pengobatan dengan tiamfenikol, sedangkan Suwangool tidak menemukan efek samping selama menggunakan tiamfenikol.

Lama rawat pasien yang mendapat kloramfenikol adalah 8,7 $\pm 2,7$ hari dan kelompok tiamfenikol adalah $8,5 \pm 1,6$ hari $(\mathrm{p}=0,80)$. Dari rerata berat badan pasien, dosis obat yang dipakai dan lama pengobatan dapat dihitung jumlah obat yang dipakai dan harga obat keseluruhan. Dilihat dari lama rawat pasien, tampak bahwa kelompok tiamfenikol dapat keluar rumah sakit 1 hari lebih cepat dibandingkan 
kelompok kloramfenikol. Walaupun secara statistik tidak berbeda bermakna $(\mathrm{p}=0,80)$, keadaan ini cukup menggembirakan bagi pasien ataupun keluarganya, sedangkan harga obat yang dipakai secara keseluruhan hanya sedikit lebih mahal dibandingkan kloramfenikol $(p=0,48)$.

\section{Kesimpulan dan Saran}

Dari penelitian ini didapatkan efektifitas klinis kloramenikol masih sangat baik. Efektifitas tiamfenikol juga sangat baik, sebanding dengan kloramfenikol, tetapi tiamfenikol mempunyai beberapa kelebihan antara lain demam lebih cepat turun, nafsu makan lebih cepat membaik serta sakit perut lebih cepat menghilang. Satu pasien secara klinis dianggap resisten terhadap kloramfenikol tetapi dapat dibuktikan secara in-vitro karena biakan tidak tumbuh. Semua isolat $S$. typhi yang tumbuh masih sensitif terhadap kloramfenikol maupun obat standar lain yaitu ampisilin dan kotrimoksazol. Pada kedua kelompok tidak ditemukan kasus yang kambuh ataupun pengidap kuman setelah pengobatan. Biaya perawatan pasien yang mendapat tiamfenikol hanya sedikit lebih mahal dibandingkan kloramfenikol.

Dalam pengobatan demam tifoid pada anak tiamfenikol dapat dijadikan sebagai obat pilihan pertama menggantikan kloramfenikol, walaupun masih perlu penelitian lebih lanjut oleh karena belum dapat dilihat angka kekambuhan dan pengidap kuman setelah pengobatan.

\section{Daftar Pustaka}

1. Sumarmo PS. Opening remarks. Dalam: Nelman RHH. penyunting. Typhoid fever, profil, diagnosis and treatment in the 1990's. The first ISAC International Symposium. Sanur, Bali, 1990:xvii.

2. Nathin MA, Sri Rezeki H. Ceftriaxon in the treatment of typhoid fever in children. Dalam: Nelman RHH. penyunting. Typhoid fever, profil, diagnosis and treatment in the 1990's. The first ISAC International Simposium. Sanur, Bali, 1990. h. 133-9.

3. Laporan Boks Infeksi Bagian Ilmu Kesehatan Anak FK UNSRI/RS M. Husin Palembang, 1998.
4. Nathin MA, Ringoringo P, Tambunan T, dkk. Antibiotic resistance pattern of paediatric typhoid fever patients at the Departement if child health, Cipto Mangunkusumo, Jakarta in 1990-1994. Dalam: Nelman RHH. Penyunting. Typhoid fever, profil, diagnosis and treatment in the 1990's. The first ISAC International Symposium. Sanur, Bali, 1990. h. 194205.

5. Azhali MS. Pengelolaan demam tifoid. Dalam: Naskah lengkap simposium Kongres Nasional Ilmu Kesehatan Anak X. KONIKA Bukit Tinggi, 1996. h. 75-84.

6. Soelistiowati S, Yati Sunarto, Soesilo H, dkk. Typhoid fever in children. Paediatr Indones, 1982; 22:136-46.

7. Iwan Sumarna S. Evaluation of laboratory data on Salmonella infection during 1984-1990 from the public health laboratory of Perum Bio Farma (Pasteur Institute). Dalam: Nelmann RHH. Penyunting. Typhoid fever, profil, diagnosis and treatment in the 1990's. The first ISAC International Symposium. Sanur, Bali, 1990. h. 211-24.

8. Gufta A. Multidrugs resistant typhoid fever in children epidemiology and therapeutic approach. The Paediatr Infect Dis J 1994; 13:134-40.

9. Bhutta ZA, Khan IA, Molla AM. Theraphy of multidrugs resistant typhoid fever with oral cefixime vs intranvenous ceftriaxone. The Paediatr Infect Dis J 1994; 13:990-4.

10. Moosa A, Rubidge CJ. Once daily ceftriaxone vs chloramphenikcol treatment of typhoid fever in children. The Paediatr Infect Dis J 1998; 10:696-9.

11. Sri Rezeki H. Masalah multidrug resistance pada demam tifoid anak. Cermin Dunia Kedokt, 1999; 124:5-8.

12. Soewandjoyo E, Suharto, Juwono R. Comparative study of ciprofloxcin vs chloramfenicol in patients with typhoid fever and pattern of bacterical sensitivity. Dalam: Nelman RHH. Typhoid fever, profil, diagnosis and treatment in the 1990's. The first ISAC International Symposium. Sanur, Bali, 1990:119-25.

13. Dawood ST. Uwaydah AK. Treatment of multiresistant Salmonella typhi with intravenous ciprofloxacin. The Paediatr Infect Dis J 1991; 10:343.

14. Dzen MS, Santoso S, Noorhamdani. Kepekaan invitro Salmonella Typosa terhadap chloramphenicol, ampicilin dan cotrimoxazole. Pharos Buletin 1999; 1:17-20.

15. Limson B, Lacson PS, Martinez D. Thiamphenicol, a new analogue of chloramphenicol, in treatment of enteric fever. Current therapeutic research 1975; 17:335-9.

16. Suwangool $\mathrm{P}$, Hanvanich $M$. Thiamphenicol in the treatment of enteric fever. J Med Ass Thailand 1983; 66:241-2.

17. Castaldo M, Frigerio G, Deel Nool L, Briante V. Speed of effect of thiamphenicol in the treatment of typhoid infection. Gazz Med It 1977; 132:647-57.

18. Frigerio G, Lodola E, Sperotti L. Thiamphenicol, experimental and clinical bases of a new antibiotic. Zambon Research lab, Italy 1967. h. 3-111. 